\title{
Lymphocyte subsets and natural killer cell cytotoxicity in intravenous drug users with HIV-1 infection among Thai population
}

\author{
Wannee Kantakamalakul, ${ }_{1}$ Suwalee Jangkhum, ${ }^{1}$ Silawun Ampol, ${ }_{1}^{1}$ Porurtai Burupharat, ${ }^{2}$ Rutt Chuachoowong, ${ }^{1, a}$ \\ Ruengpung Sutthent, ${ }^{1}$ Kovit Pattanapanyasat, ${ }^{3 *}$
}

\begin{abstract}
Background: Intravenous drug users (IVDUs) are among the high-risk groups who are most vulnerable to HIV infection. Several illicit drugs alter host immune function with increased incidence of infections including that of HIV. Many studies of the immune response of NK cells in HIV-1 seronegative IVDUs and HIV-1 seropositive IVDUs have been published from the Western countries and yet no data is available from Thailand.
\end{abstract}

Objective: To determine natural killer cell cytotoxicity and lymphocyte subsets in Thai HIV-1 infected intravenous drug users.

Methods: The NK cell cytotoxic function was determined using our well-established EGFP-K562 flow cytometric assay in 30 IVDUs with HIV-1 infection (IVH) comparing with those from the same number of non-infected IVDUs (IVX), HIV-1 seropositive individuals (HIV-1+ve) and healthy controls. The percentage and the absolute number of NK cells, helper $\mathrm{CD}^{+} \mathrm{T}$ cells and cytotoxic $\mathrm{CD} 8^{+} \mathrm{T}$ cells were also investigated.

Results: Among the study groups, IVH showed not only the lowest percentage of lytic activity by NK cells, but also a decline in the percentage and absolute count of NK cells. A decline in helper $\mathrm{CD} 4^{+} \mathrm{T}$ cells and an increase of cytotoxic $\mathrm{CD}^{+} \mathrm{T}$ cells of IVH group when compared to those of other 3 groups were also demonstrated.

Conclusions: The failure of innate immune NK cell function and their number in IVH may support the involvement of additional components of the immune system in the control of HIV-1 disease.

Keywords: NK cells; NK cell cytotoxicity; CD4+ T cells; CD8 ${ }^{+}$T cells; HIV-1; intravenous drug users

\footnotetext{
From:

${ }^{1}$ Department of Microbiology, Faculty of Medicine Siriraj Hospital, Mahidol University, Bangkok, Thailand

2 The Public Health Center 3 (Bang Sue), Health Department, Bangkok Metropolitan Administration, Bangkok, Thailand

Center of Excellence for Flow Cytometry, Department of Research and Development, Faculty of Medicine Siriraj Hospital, Mahidol University, Bangkok, Thailand
}

\section{Introduction}

Human immunodeficiency virus (HIV)/AIDS is still a major global health problem with an estimated 35.3 million people are living with HIV. ${ }^{1}$ In Thailand, more than 1 million of HIV-1 infected people were reported in $2015 .^{2}$ Of the estimated 440,000 people living with HIV, the relatively high levels of prevalence were in men who have sex with men, transgender people, male/female sex workers and their partners, migrant workers and intravenous drug users (IVDUs).

\author{
${ }^{a}$ Present address: \\ Sanofi-Aventis (Thailand) Ltd., Thailand \\ * Corresponding author: \\ Kovit Pattanapanyasat \\ Email: kovit.pat@mahidol.ac.th
}

Interestingly, the HIV-1 prevalence among the Thai IVDUs has the highest HIV-1 prevalence (about 30-50\%) comparing to other risk groups of HIV-1 infection ${ }^{3}$ with predominantly a CRF01_AE subtype. ${ }^{4-6}$ It has been known that illicit drugs alter immune unction and decrease host resistance to microbes with increased incidence of infections or immune disorders in humans, including infection with HIV and disease progression to AIDS. ${ }^{7,8}$ 
Human natural killer (NK) cells are large granular lymphocytes of the innate immune system. ${ }^{9} \mathrm{NK}$ cells are recognized as a subset of cytotoxic innate lymphoid cells which play a role in the killing of tumor and virus-infected cells and participate in shaping the adaptive immunity by secretion of cytokines. ${ }^{10}$ NK cells are cytotoxic with small granules in their cytoplasm contain proteins such as perforin and proteases known as granzymes, these proteins are released when they encounter with an infected cell by inducing either apoptosis or osmotic cell lysis. ${ }^{11,12}$ NK cells can also recognize and lyse target cells by antibody dependent cell-mediated cytotoxicity (ADCC). The increased risk for the disease progression in HIV-infected individuals are associated not only with the low number of the NK cells but also with the defect in their cytotoxic activity ${ }^{11}$ and also with decline of helper $\mathrm{CD} 4^{+} \mathrm{T}$ cells and the accumulation of cytotoxic $\mathrm{CD}^{+} \mathrm{T}$ cells. ${ }^{13,14}$

Although there are many studies of the innate immune response of NK cells in HIV-1 seronegative IVDUs and HIV-1 seropositive IVDUs, ${ }^{15-18}$ the study of NK cells due to the HIV-1 infection and/or intravenous drug abuse in Thais has not been conducted. In this study, we used our well-established enhanced green fluorescent protein (EGFP)-K562 flow cytometric method ${ }^{19}$ for measuring the NK cell function in IVDUs with HIV-1 infection (IVH). Results were also compared with those from HIV-1 infected individuals (HIV-1+ve) and non -infected IVDUs (IVX) as well as healthy individuals.

\section{Methods \\ Study population and blood samples}

Thirty HIV-1 uninfected IVDUs, 22 males and 8 females, and $30 \mathrm{HIV}-1$ infected IVDUs, 24 males and 6 females, at Public Health Center 3 (Bang Sue), Health Department, Bangkok Metropolitan Administration were enrolled in this study with written informed consents. All volunteers were documented to have treatment for drug addiction. All 30 HIV-1 infected IVDUs had previously tested once for HIV-1 antigen in saliva at this center. Fresh venipuncture Acid citrate dextrose solution B (ACD, Becton Dickinson Biosciences $\{B D B\}, C A, U S A)$ blood samples and Tripotassiumethylenediamine tetra-acetate $\left(\mathrm{K}_{3} \mathrm{EDTA}, \mathrm{BDB}\right)$ blood samples from each subject were collected. Complete blood counts (CBC) of each blood sample was performed at the laboratory of Department of Clinical Pathology, Faculty of Medicine Siriraj Hospital by using automate hematological analyzer Sysmex XE-5000 (Sysmex Corporation, Kobe, Japan).

Leuko-pak and $\mathrm{K}_{3}$ EDTA blood from 30 asymptomatic HIV-1 infected blood donors, 22 males and 8 females, were kindly provided by the Department of Transfusion Medicine, Faculty of Medicine Siriraj Hospital and Thai Red Cross. Thirty healthy HIV-1 seronegative blood subjects, 23 males and 7 females were also recruited from the blood bank donors. All samples obtained had no donor identifiers. There were no differences in the base line characteristics of all 4 study groups, i.e., age, sex ratio.

This study was approved by Ethics Committee of the Bangkok Metropolitan Administration for IVDUs subjects (No. 147-2009) and Institutional Review Board, Faculty of Medicine Siriraj Hospital (COA: Si031/2007) for all samples.

\section{Immunophenotyping staining of peripheral blood samples}

Percentages and absolute cell numbers of NK cells (CD3 $\left.\mathrm{CD} 16^{+} \mathrm{CD} 56^{+}\right)$, helper $\mathrm{CD} 4^{+} \mathrm{T}$ cells $\left(\mathrm{CD} 3^{+} \mathrm{CD} 4^{+}\right)$and cytotoxic $\mathrm{CD} 8^{+} \mathrm{T}$ cells $\left(\mathrm{CD}^{+}{ }^{+} \mathrm{CD} 8^{+}\right)$were determined by standard TriTESTmethod ${ }^{20,21}$ using BD Tritest ${ }^{\mathrm{mm}}$ monoclonal antibody (mAb) reagents. Briefly, ten $\mu \mathrm{l}$ of TriTEST 3-color mAb reagents were mixed with $50 \mu \mathrm{l}$ of EDTA-anticoagulated whole blood and incubated for $20 \mathrm{~min}$ at room temperature in the dark before adding $450 \mu \mathrm{l}$ of FACS Lysing Solution (BDB). After an incubation time of $15 \mathrm{~min}$, the cells were washed at 1,400 $\mathrm{rpm}$ for $5 \mathrm{~min}$. The cell pellet was resuspended in $300 \mu \mathrm{l}$ of $1 \%$ paraformaldehyde and kept at $2-8^{\circ} \mathrm{C}$ until analysis by FACSCalibur flow cytometer (BDB). Percentages of NK cells, helper $\mathrm{CD}^{+} \mathrm{T}$ cells and cytotoxic $\mathrm{CD} 8^{+} \mathrm{T}$ cells were obtained by using CellQuest ${ }^{\mathrm{TM}}$ Analysis software (BDB). The absolute cell numbers of these lymphocyte subsets were determined by multiplying the percentage of each subset with the absolute lymphocyte counts from the $\mathrm{CBC}$.

\section{Preparation of effector cells}

Peripheral blood mononuclear cells (PBMCs) from each ACD blood sample were separated by standard ficoll-hypaque density gradient centrifugation, washed three times with $0.2 \mathrm{M}$ phosphate buffered saline (PBS) and resuspended in freezing medium containing 60\% RPMI 1640 (Gibco Laboratories, Grand Island, NY, USA), 30\% fetal bovine serum (FBS, Gibco Laboratories) and 10\% dimethyl sulfoxide (Sigma-Aldrich Corp, MO, USA). Aliquots of PBMCs at a density of $5 \times 10^{6}$ cells $/ \mathrm{ml}$ were cryopreserved in liquid nitrogen until use. One day prior to the experiment, PBMCs were thawed and added to $100 \mathrm{~mm}$ polystyrene tissue culture plates (Griener Bio-One $\mathrm{GmbH}$, Frickenhausen, Germany) and incubated overnight at $37^{\circ} \mathrm{C}$ with $5 \% \mathrm{CO}_{2}$ to deplete adherent monocytes. The non -adherent lymphocytes were collected and resuspended at a density of $1 \times 10^{6}$ for use as effector cells in the NK cell cytotoxicity assay.

\section{Preparation of target cells}

The EGFP-K562 cell line was prepared as previously described ${ }^{19}$ and used as targets for measuring NK cell cytotoxicity by flow cytometry. This cell line was cultured in growth medium containing RPMI 1640 supplemented with $2 \mathrm{mM}$ L-glutamine (Gibco Laboratories), $100 \mu \mathrm{g} / \mathrm{ml}$ streptomycin (Gibco Laboratories), $100 \mathrm{IU} / \mathrm{ml}$ penicillin (Gibco Laboratories), and 10\% heat inactivated FBS (Gibco Laboratories) and $400 \mu \mathrm{g} / \mathrm{ml}$ of neomycin analogue G-418 (Roche Diagnostics, IN, USA). Prior to the experiment, the target cells were resuspended in growth medium at a density of $1 \times 10^{5} \mathrm{cells} / \mathrm{ml}$.

\section{NK cytotoxicity flow cytometry assay}

The EGFP-K562 flow cytometric assay for measuring NK cytotoxicity was based on a method previously described. ${ }^{19}$ Briefly, four hundred microliters of PBMCs as effector cells at a density of $1 \times 10^{6}$ cells $/ \mathrm{ml}$ were added into individual round bottom $12 \times 75 \mathrm{~mm}$ polystyrene (Falcon) tubes (BDB) with 2 -fold serial diluted in 10\% RPMI 1640 growth medium. Fifty microliters of EGFP-K562 target cells as a density of $1 \times 10^{5}$ cells $/ \mathrm{ml}$ were added into each tube to yield the effectors per 
target cells (E/T) ratios of 80:1 and 40:1. All sample tubes were mixed and incubated at $37^{\circ} \mathrm{C}$ with $5 \% \mathrm{CO}_{2}$ for 4 hours. After incubation, propidium iodide (PI) (Sigma-Aldrich Corp) solution at a concentration of $100 \mu \mathrm{g} / \mathrm{ml}$ was added into the tubes to stain compromised or dead cells and then the tubes were incubated at room temperature for 10 minutes. The cytotoxic activity of NK cells to lyse target cells was measured by using a FACSCalibur flow cytometer (BDB). For measuring the percent lysis of NK cytotoxicity, exactly $2 \times 10^{4}$ events per test sample were examined and no gating was used for acquisition. The threshold for side scatter (SSC) was set on the linear scale to discriminate the debris and dead cells. Two parameters of the forward and side scatter (FSC/SSC) dot plots signals were analyzed by using CELLQuest ${ }^{\mathrm{TM}}$ software (BDB) (Figure 1A). The EGFP versus PI data were obtained to evaluate live and dead target cells using log scale of green fluorescent (FL1) or EGFP in the $\mathrm{X}$ axis and the log scale of red fluorescent (FL2) or PI in the Y axis (Figure 1B). The strong green fluorescent at the lower right (LR) quadrant were identified as the live target cells whereas the red and green fluorescent on the upper right

A

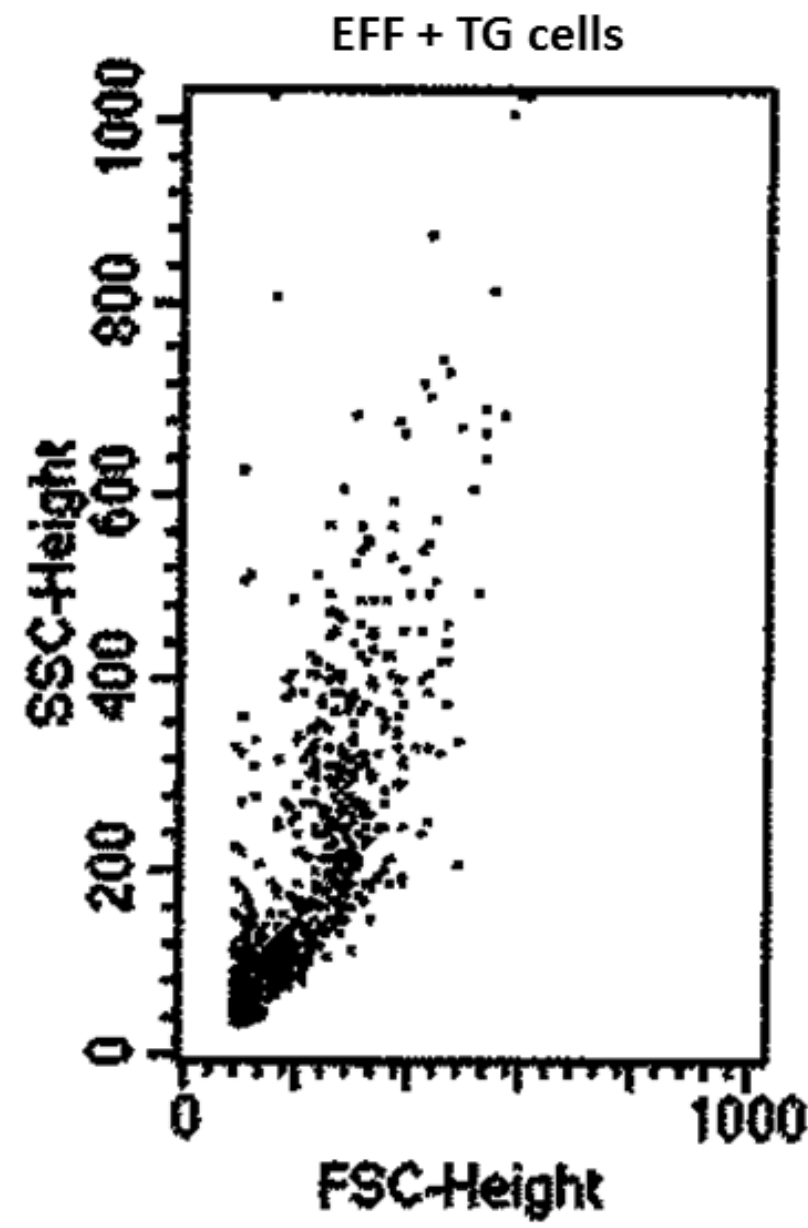

(UR) quadrant were identified as compromised or dead target cells. The red fluorescence on the upper left (UL) quadrant were defined as the autodamaged or potentially lysed effector cells or target cells with decreased EGFP whereas the lower left (LL) were considered to be the living effecter cells or living target cells with weak green fluorescence. Effector cells alone and target cells alone stained with PI were used as controls. The percentage of target cell lysis was calculated by using the following formula: $\%$ Lysis $=(\mathrm{UR} / \mathrm{UR}+\mathrm{LR}) \times 100$.

\section{Statistical analysis}

Statistical analysis in this study was conducted on SPSS software version 11.5 (SPSS Inc., NY, USA). Statistical significance within group was analyzed by Shapiro-Wilk test and statistical significance between groups was analyzed with one -way ANOVA test. The significant level of each test between groups was adjusted by multiple testing using Bonferroni and Tamhane correction for homogeneity and heterogeneity of variance, respectively. The significant threshold of four comparisons of each test was set at $\mathrm{p}$ value $<0.05$.
B

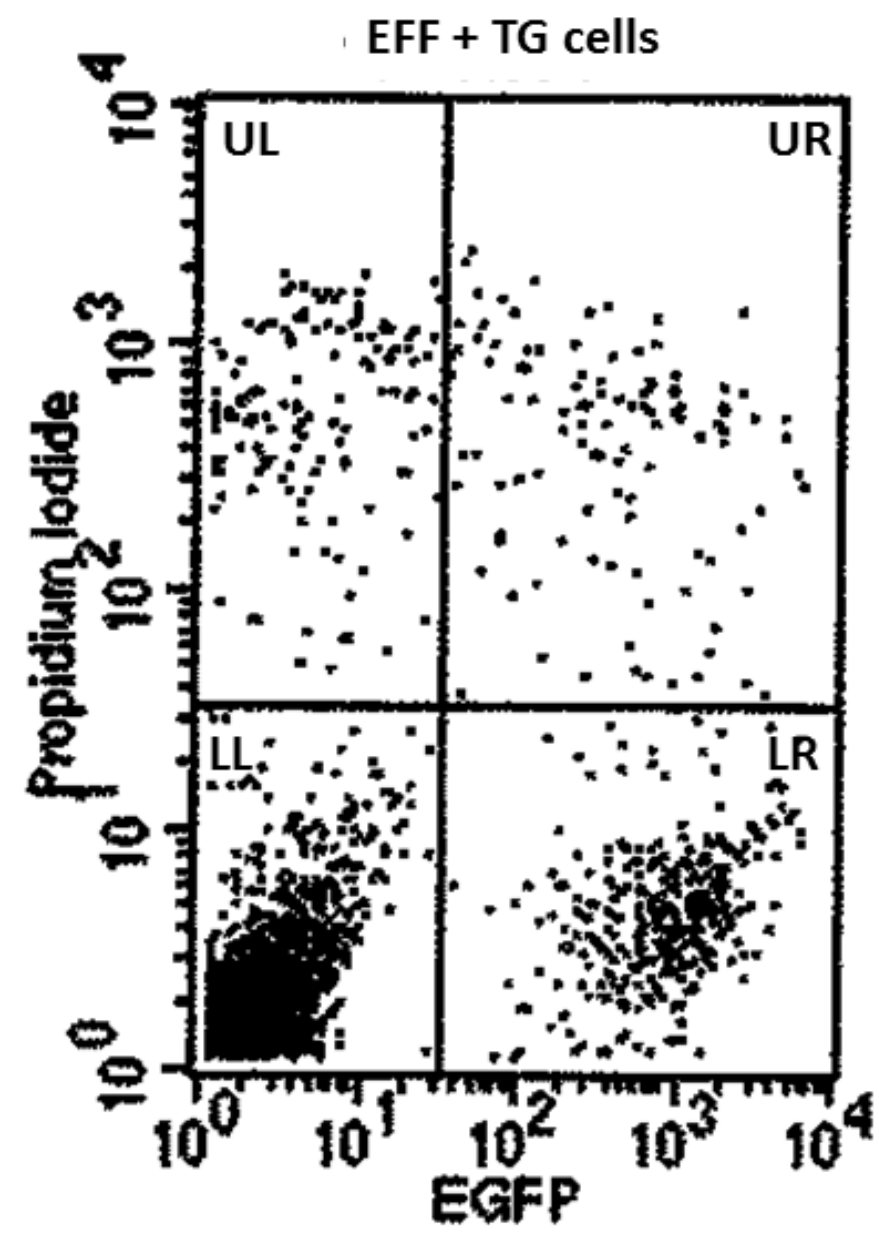

Figure 1. Representative flow cytometric two-parameter dot-plots on NK cytotoxicity test showing Forward Scatter (FSC) vs. Side Scatter (SSC) of NK (effector) cells and EGFP-K562 (target) cells A) and logarithmic EGFP vs. propidium iodide expression of live and dead effector vs. target cells (B). Cells at the lower right (LR) quadrant are lived target cells whereas the red and green fluorescent on the upper right (UR) quadrant are dead target cells. Cells at the upper left (UL) quadrant are defined as the autodamaged or potentially lysed effector cells or target cells with decreased EGFP whereas the lower left (LL) quadrant represents the living effecter cells or living target cells with weak green fluorescence. 


\section{Results}

Characteristics of study populations

Characteristics of Thai HIV-1 seronegative individuals (Healthy), HIV-1 seronegative IVDUs (IVX), HIV-1 seropositive individuals (HIV-1+ve) and HIV-1 seropositive IVDUs (IVH) in this study were shown in Table 1. Healthy group did not have any vaccination at least one year prior to this study. In IVX group, there was only one participant with history of Hepatitis B virus infection. All subjects in IVH group had received tenofovir as antiretroviral drugs. All IVDUs subjects had history for multiple intravenous and inhalation drug behaviors. Their drugs used within the 3-month period prior to blood collection were mainly heroin, methamphetamine, domicum and cannabis for both IVX and IVH groups. Within the IVX group, the percentage of participants that used injecting drugs was $66 \%$ heroin, $52.4 \%$ methamphetamine and $28.6 \%$ domicum, and inhalation drugs was $68.8 \%$ methamphetamine and $56.3 \%$ cannabis (Table 1). For the IVH group, the percentage was $37.5 \%$ heroin, $58.3 \%$ methamphetamine and $54.2 \%$ domicum, and inhalation drugs was $83.3 \%$ methamphetamine and $61.1 \%$ cannabis (Table $\mathbf{1}$ ).

Percentages and absolute counts of $\mathrm{NK}$ cells, helper $\mathrm{CD4}^{+} \mathrm{T}$ cells and cytotoxic $\mathrm{CDB}^{+} \mathrm{T}$ cells in the study populations

Mean percentages and absolute counts of each lymphocyte subset among the study populations were compared and shown in Table 2. The mean percentages of helper $\mathrm{CD}^{+} \mathrm{T}$ cells of IVH group and HIV-1+ve group were significantly lower than those of IVX group and healthy group. No statistically significant difference among the two HIV-1 infected groups (IVH group vs. HIV-1+ve group) and among the two HIV-1 seronegative groups (IVX group vs. healthy group) were found. The mean absolute counts of helper $\mathrm{CD}^{+} \mathrm{T}$ cells from IVH group were significant decreased $(\mathrm{p} \leq 0.001)$ when compared with those from HIV-1+ve, IVX, and the healthy groups. Interestingly, the absolute counts of helper $\mathrm{CD}^{+} \mathrm{T}$ cells from IVX group were significantly higher than those of healthy and HIV-1+ve groups ( $p$ value $\leq 0.05$ ) while those of healthy and HIV-1+ve groups were comparable.

For cytotoxic $\mathrm{CD}^{+} \mathrm{T}$ cells, the mean percentages in HIV-1 +ve group and IVH group were significantly higher $(\mathrm{p} \leq 0.05)$ than those of healthy group and IVX group. No statistically significant differences among the HIV-1+ve and IVH groups and among the IVX and healthy groups were seen (Table 2). Comparison of the absolute counts of cytotoxic $\mathrm{CD} 8^{+} \mathrm{T}$ cells among the study groups showed that HIV-1+ve group had a significant increase $(\mathrm{p} \leq 0.05)$ in the absolute counts when compared with those of IVH, IVX and the healthy groups. Moreover, no significant difference among the healthy, IVX and IVH groups were observed.

Among the study groups, the mean percentage of NK cells was significantly decreased $(\mathrm{p} \leq 0.05)$ in IVH group when compared to those from healthy group but did not show any significant difference to those of HIV-1+ve group and IVX

Table 1. Demographics and characteristics of the study populations.

\begin{tabular}{|c|c|c|c|c|c|c|c|c|c|}
\hline \multirow{2}{*}{ Group } & \multirow{2}{*}{ Subjects } & \multirow{2}{*}{$\begin{array}{c}\text { Age (yrs) } \\
\text { Mean } \pm \text { SD }\end{array}$} & \multicolumn{2}{|c|}{ Gender } & \multicolumn{3}{|c|}{ Injecting drug (\%) } & \multicolumn{2}{|c|}{ Inhalation drug (\%) } \\
\hline & & & Male & Female & Heroin & Methamphetamine & Domicum & Methamphetamine & Cannabis \\
\hline Healthy & 30 & $30 \pm 6.7$ & 23 & 7 & - & - & - & - & - \\
\hline IVX & 30 & $39 \pm 6.9$ & 22 & 8 & 66.6 & 52.4 & 28.6 & 68.8 & 56.3 \\
\hline HIV-1+ve & $30^{\mathrm{a}}$ & $31 \pm 9.1$ & 22 & 8 & - & - & - & - & - \\
\hline IVH & $30^{\mathrm{b}}$ & $39 \pm 8.1$ & 24 & 6 & 37.5 & 58.3 & 54.2 & 83.3 & 61.1 \\
\hline
\end{tabular}

IVX $=$ HIV-1 seronegative IVDUs; IVH = HIV-1 seropositive IVDUs

${ }^{a}$ unknown history of antiretroviral drug treatment; ${ }^{\mathrm{b}}$ all subjects received tenofovir as antiretroviral drugs.

Table 2. Comparison of percentages and absolute counts of helper $\mathrm{T}$ cells $\left(\mathrm{CD}^{+} \mathrm{CD}^{+}\right)$, cytotoxic $\mathrm{T}$ cells $\left(\mathrm{CD}^{+} \mathrm{CD8}^{+}\right)$and $\mathrm{NK}$ cells $\left(\mathrm{CD} 3 \mathrm{CD}^{-} 6^{+} \mathrm{CD} 56^{+}\right)$in the 4 study groups.

\begin{tabular}{|c|c|c|c|c|c|}
\hline \multirow{2}{*}{ Parameter } & \multicolumn{4}{|c|}{ Mean \pm SD } & \multirow{2}{*}{$p$-value } \\
\hline & Healthy gr. & IVX gr. & HIV-1 +ve gr. & IVH gr. & \\
\hline $\begin{array}{l}\text { Helper T cells } \\
\% \\
\text { cells } / \mu \mathrm{l}\end{array}$ & $\begin{array}{c}33.25 \pm 5.58 \\
784 \pm 261\end{array}$ & $\begin{array}{c}36.39 \pm 8.78 \\
1104 \pm 526\end{array}$ & $\begin{array}{c}22.39 \pm 9.71^{\star} \\
732 \pm 581\end{array}$ & $\begin{array}{c}19.99 \pm 6.36^{*} \\
358 \pm 206^{* *}\end{array}$ & $\begin{array}{l}\leq 0.05 \\
\leq 0.001\end{array}$ \\
\hline $\begin{array}{l}\text { Cytotoxic T cells } \\
\% \\
\text { cells } / \mu \mathrm{l}\end{array}$ & $\begin{array}{c}30.61 \pm 6.07 \\
657 \pm 268\end{array}$ & $\begin{array}{c}26.07 \pm 8.16 \\
757 \pm 390\end{array}$ & $\begin{array}{c}49.38 \pm 13.21^{*} \\
1380 \pm 874^{*}\end{array}$ & $\begin{array}{c}51.09 \pm 9.52^{*} \\
948 \pm 406\end{array}$ & $\begin{array}{l}\leq 0.05 \\
\leq 0.05\end{array}$ \\
\hline $\begin{array}{l}\text { NK cells } \\
\begin{array}{l}\% \\
\text { cells } / \mu l\end{array}\end{array}$ & $\begin{array}{c}18.99 \pm 5.30 \\
458 \pm 189\end{array}$ & $\begin{array}{c}15.62 \pm 7.74 \\
451 \pm 303\end{array}$ & $\begin{array}{c}14.55 \pm 10.87 \\
380 \pm 320\end{array}$ & $\begin{array}{c}11.10 \pm 6.47^{\$} \\
188 \pm 115^{\star *}\end{array}$ & $\begin{array}{l}\leq 0.05 \\
\leq 0.05\end{array}$ \\
\hline
\end{tabular}

* Statistical difference when compared to the Healthy and IVX groups.

** Statistical difference when compared to the Healthy, IVX and HIV+ve groups.

${ }^{\$}$ Statistical difference when compared to the Healthy group. 
Table 3. Comparison of NK cytotoxicity function in the $\mathbf{4}$ study groups.

\begin{tabular}{|l|c|c|c|c|}
\hline \multirow{2}{*}{ E/T ratio } & \multicolumn{3}{|c|}{ Mean \pm SD of \% lysis of NK cytotoxicity in } \\
\cline { 2 - 5 } & Healthy gr. & IVX gr. & HIV-1 +ve gr. & \multicolumn{2}{c|}{ IVH gr. } \\
\hline $\mathbf{8 0 : 1}$ & $41.78 \pm 7.99$ & $52.02 \pm 13.68$ & $41.06 \pm 11.23$ & $33.77 \pm 10.02^{*}$ \\
\hline $\mathbf{4 0 : 1}$ & $30.91 \pm 8.77$ & $35.58 \pm 15.40$ & $29.64 \pm 8.29$ & $23.20 \pm 9.71^{*}$ \\
\hline
\end{tabular}

* Statistical difference when compared to the Healthy, IVX, and HIV+ve groups.

group. No significant differences in mean percentages of NK cells were found among the HIV+ve, IVX and the healthy groups (Table 2). For the absolute counts of NK cells, the IVH group showed significant decrease $(\mathrm{p} \leq 0.05)$ in the absolute counts when compared with those of HIV+ve, IVX and the healthy groups. No significant differences among the healthy, IVX and HIV-1+ve groups were found.

\section{NK cell cytotoxicity in the study populations}

Comparison of the mean percentages of EGFP-K562 target cell lysis at the E:T ratios of 80:1 and 40:1 by NK cells from the 4 study groups showed that the IVH group showed significantly decreased of NK cytotoxicity $(\mathrm{p} \leq 0.05)$ at the E:T ratio of 80:1 and 40:1 when compared to the other groups (Table 3). Interestingly, the mean lysis percentages of NK cytotoxicity in IVX group at both $\mathrm{E} / \mathrm{T}$ ratios were significantly higher ( $\mathrm{p}$ $\leq 0.05$ ) than those in HIV-1+ve, IVH and the healthy groups, particularly at E:T ratio of 80:1. Moreover, no difference of the mean percentages lysis activity between the healthy and the HIV-1+ve groups were shown.

\section{Discussion}

It is estimated that worldwide there are almost 13 million people who are IVDUs. Out of these nearly 2 million, or $15 \%$, are also living with HIV which is typically far greater than it is among the rest of the adult population, with IVDUs bearing a 28 times higher prevalence. ${ }^{22}$ In Thailand, there were an estimated 440,000 people living with HIV in Thailand in 2015 with an estimation of adult HIV prevalence of $1.1 \%$ out of Thailand's population of more than 60 million. Among 6,900 new HIV infections in 2015, unsafe injecting drug use is the second biggest transmission route which account for $12 \% .{ }^{23}$ During HIV-1 infection several immunological abnormalities have been found in IVDUs. ${ }^{5,8}$ It has been known that the increased risk for the disease progression in HIV-infected individuals is associated with the decline of helper $\mathrm{CD} 4^{+} \mathrm{T}$ cells and the accumulation of cytotoxic $\mathrm{CD}^{+} \mathrm{T}$ cells with a more rapid helper $\mathrm{CD}^{+} \mathrm{T}$ cell decline among HIV-1 infected IVDUs. ${ }^{24}$ Biological factors such as effect of opioids, co-infection with other diseases such as TB or hepatitis C, even a difference in tropism with virulent strain of HIV transmitted among the IVDUs are all responsible for the faster decline in helper $\mathrm{CD}^{+} \mathrm{T}$ cells. ${ }^{25,26} \mathrm{~A}$ decline in both percentages and absolute counts of helper $\mathrm{CD} 4^{+} \mathrm{T}$ cells with marked increases in percentages and absolute counts of cytotoxic CD8 ${ }^{+} \mathrm{T}$ cells in our IVH group support the above findings. Although there was no history of how fast the decrease of helper $\mathrm{CD} 4^{+} \mathrm{T}$ cells in our IVH group as only one blood sample at one time point was obtained, our IVH group showed more helper $\mathrm{CD}^{+} \mathrm{T}$ cell decline than those in HIV+ve group. This may indicate the problems with an irregular adherence to antiretroviral drugs, loss of follow-up or lower access to health services in our IVH group. Unlike the decline helper T cells found in IVH group, our HIV+ve group showed higher helper $\mathrm{CD}^{+}$ $\mathrm{T}$ cell counts than the IVH group implying that there was a good suppressing HIV replication in these asymptomatic HIV-1 infected blood donors. Unfortunately, the history of antiretroviral drug treatment was not available for this group.

NK cells have been described for the innate mechanism as the first line defense against HIV-1 infection and may help mediating adaptive immune responses. ${ }^{10-12}$ It has been shown that $\mathrm{NK}$ cell effect or function that mediated $\mathrm{NK}$ cell cytotoxicity are impaired during the course of HIV-1 disease ${ }^{26}$ but enhanced during HIV-1 viremia. ${ }^{27}$ Previous studies on the NK profiles from the cohort of HIV-1 exposed, uninfected IVDUs demonstrated the enhancement of NK activity, high $\mathrm{NK}$ activation as represented by $\mathrm{CD}^{+} 8^{+}$cells, and the CD4 and CD8 cell-mediated resistance to HIV-1 infection. ${ }^{18,28,29}$ However, there is limited information available regarding the effect of HIV-1 infection on the NK profile in Thai IVDUs. Our NK cytotoxicity study in IVDUs showed significantly decreased of lysis activity in IVH group when compared to those of healthy, HIV-1+ve and IVX groups. When defining the percentage and absolute count of NK cells, our study showed significant decrease of both the percentage and the absolute count of NK cells in IVH group when compared to those of healthy, HIV-1+ve and IVX groups. This data suggested the inverse effect to the NK cell numbers due to HIV-1 infection along with the use of injecting drugs. Our findings also support that the drug abuse has immune-modulating effects which could alter the progression of HIV infection. ${ }^{30,31}$

Of interest is that the NK functional activity in our IVX group was significantly increased when compared to the other 3 groups. The increased NK cell lysis activity in the IVX who are a high-risk group, could due to different mechanisms related either to immune responses and/or to genetic background contribute to the resistance to infection in the highly exposed but uninfected (EU) IVDUs. Our results support the contentions of enhanced innate immune cell function in EU individuals especially when compare with IVDUs who became HIV-1 infected. ${ }^{28}$ There was no difference of the mean percentages NK celllys is activity between the healthy and the HIV-1+ve groups. This may be due to the asymptomatic stage of our HIV+ve individuals whose NK cell functions were still normal. When defining the percentage and absolute count of NK cells, our study demonstrated that not only there was no significant difference of the mean 
percentages of NK lysis activity among the HIV+ve, IVX and the healthy groups, but also there was no difference in percentages and the absolute counts of NK cells. Our findings are in line with de Souza et al. who reported that NK cell cytotoxicity and NK cell counts are not different between Thai HIV-1 seronegative and Thai HIV-1 seropositive subjects. ${ }^{32}$

In conclusion, our study shows that IVHs have alterations in the lymphocyte subsets evidenced by a decrease in helper $\mathrm{CD}^{+} \mathrm{T}$ cells and an increase in cytotoxic $\mathrm{CD} 8^{+} \mathrm{T}$ cells along with a lower number of NK cells and their impaired cytotoxic function. The data suggest that the failure of innate immune NK cell function and their number with possible link to decrease in helper $\mathrm{CD}^{+} \mathrm{T}$ cells and increase in cytotoxic $\mathrm{CD} 8^{+}$ $\mathrm{T}$ cells, may contribute to the ineffective immune surveillance and potentially predisposing them to progressive disease.

\section{Acknowledgements}

We would like to thank all HIV-1 infected IVDUs and non-infected IVDUs from the Public Health Center 3 (Bang Sue), Health Department, Bangkok Metropolitan Administration for the donation of the blood samples. We also thank the Department of Transfusion Medicine, Faculty of Medicine Siriraj Hospital and Thai Red Cross for HIV-1 infected- and healthy blood-samples. Part of this work was financially supported by Thailand Research Fund (TRF) - Distinguished Research Professor Grant, grant no. DPG5980001 to KP. No conflicts of interest regarding any aspect of this study.

Author's contributions: SJ and SA were contributors for performing experiments including collection of data, analysis; $\mathrm{PB}$ and $\mathrm{RC}$ were responsible on recruitment of IVDUs and blood collection. RS oversaw the collection of data, analysis and interpretation; WK and KP were the main contributors to the design and direction of the study including writing the manuscript. KP is the corresponding author.

\section{References}

1. UNAIDS. Joint United Nations Programme on HIV/AIDS:Global report on the global AIDS epidemic 2013[Internet].Geneva:UNAIDS; c2017 [cited 2017 Oct 25]. Available from:

http://www.unaids.org/globalreport/global_report.html

2. AVERT. Global information and education on HIV and AIDS: HIV and AIDS in Thailand 2017 [Internet].UK: AVERT; c2017 [cited 2017 Oct 31]. Available from:

https://www.avert.org/professionals/hiv-around-world/asia-pacific/thailan d\#footnote32_3q0sa9g

3. UNAIDS. Joint united nations programme on HIV/AIDS:Global report on the global AIDS epidemic 2010[Internet]. Geneva:UNAIDS; c2017 [cited 2017 Oct 25]. Available from: http://www.unaids.org/globalreport/global_report.html

4. Tovanabutra S, Beyrer C, Sakkhachornphop S, Razak MH, Ramos GL, Vongchak $\mathrm{T}$, et al. The changing molecular epidemiology of HIV type 1 among northern Thai drug users, 1999 to 2002. AIDS Res Hum Retroviruses. 2004;20:465-75.

5. Wasi C, Herring B, Raktham S, Vanichseni S, Mastro TD, Young NL, et al. Determination of HIV-1 subtypes in injecting drug users in Bangkok, Thailand, using peptide-binding enzyme immunoassay and heteroduplex mobility assay: evidence of increasing infection with HIV-1 subtype E. AIDS. 1995;9:843-9.

6. Xiridou M, van Griensven F, Tappero JW, Martin M, Gurwith M, Vanichseni S, et al. The spread of HIV-1 subtypes B and CRF01_AE among injecting drug users in Bangkok, Thailand. J Acquir Immune Defic Syndr. 2007;45:468-75.

7. Cabral GA. Drugs of abuse, immune modulation, and AIDS. J Neuroimmune Pharmacol. 2006;1:280-95.
8. Friedman H, Pross S, Klein TW. Addictive drugs and their relationship with infectious diseases. FEMS Immunol Med Microbiol. 2006;47:330-42.

9. Gregoire C, Chasson L, Luci C, Tomasello E, Geissmann F, Vivier E, et al. The trafficking of natural killer cells. Immunol Rev. 2007;220:169-82.

10. Vivier E, Raulet DH, Moretta A, Caligiuri MA, Zitvogel L, Lanier LL, et al. Innate or adaptive immunity? The example of natural killer cells. Science. 2011;331:44-9.

11. Rousalova I, Krepela E. Granzyme B-induced apoptosis in cancer cells and its regulation (review). Int J Oncol. 2010;37:1361-78.

12. Trapani JA, Smyth MJ. Functional significance of the perforin/granzyme cell death pathway. Nat Rev Immunol. 2002;2:735-47.

13. Ananworanich J, Apornpong $\mathrm{T}$, Kosalaraksa $\mathrm{P}$, Jaimulwong $\mathrm{T}$, Hansudewechakul R, Pancharoen C, et al. Characteristics of lymphocyte subsets in HIV-infected, long-term nonprogressor, and healthy Asian children through 12 years of age. J Allergy ClinImmunol. 2010;126: 1294-301.

14. Zucchini N, Crozat K, Baranek T, Robbins SH, Altfeld M, Dalod M. Natural killer cells in immunodefense against infective agents. Expert Rev Anti Infect Ther. 2008;6:867-85.

15. Baldwin GC, Roth MD, Tashkin DP. Acute and chronic effects of cocaine on the immune system and the possible link to AIDS. J Neuroimmunol. 1998;83:133-8.

16. Poli G, Introna M, Zanaboni F, Peri G, Carbonari M, Aiuti F, et al. Natural killer cells in intravenous drug abusers with lymphadenopathy syndrome. Clin Exp Immunol. 1985;62:128-35.

17. Ravet S, Scott-Algara D, Bonnet E, Tran HK, Tran T, Nguyen N, et al. Distinctive NK-cell receptor repertoires sustain high-level constitutive NK-cell activation in HIV-exposed uninfected individuals. Blood. 2007; 109:4296-305.

18. Tomescu C, Duh FM, Lanier MA, Kapalko A, Mounzer KC, Martin MP, et al. Increased plasmacytoid dendritic cell maturation and natural killer cell activation in HIV-1 exposed, uninfected intravenous drug users. AIDS. 2010;24:2151-60.

19. Kantakamalakul W, Jaroenpool J, Pattanapanyasat K. A novel enhanced green fluorescent protein (EGFP)-K562 flow cytometric method for measuring natural killer (NK) cell cytotoxic activity. J Immunol Methods. 2003;272:189-97.

20. Nicholson JKA, Jones BM, Hubbard M. CD4 T-lymphocyte determinations on whole blood specimens using a single-tube three-color assay. Cytometry. 1993;14:685-9.

21. Pattanapanyasat K, Pengruangrojanachai V, Thepthai C, Suwanagool, Wasi C. Flow cytometric three-color determination of CD4 T-lymphocytes on blood specimens from AIDS patients who have a large number of contaminated non-lymphocytes. Asian Pac J Allergy Immunol. 1994;12:105-9.

22. UNAIDS. People who inject drugs. The GAP report 2014[Internet]. Geneva: UNAIDS; c2017 [cited 2017 Oct 31]. Available from: http://www.unaids.org/sites/default/files/media_asset/05_peoplewhoinject drugs.pdf

23. Global AIDS update 2016 - unaids. Global AIDS Response Progress Reporting (GARPR) 2016[Internet]. Geneva: UNAIDS; c2017 [cited 2017 Oct 25]. Available from:

http://www.unaids.org/sites/default/files/media_asset/global-AIDS-update -2016_en.pdf

24. Meijerink H, Wisaksana R, Iskandar S, den Heijer M, van der Ven AJAM, Alisjahbana $\mathrm{B}$, et al. Injecting drug use is associated with a more rapid CD4 cell decline among treatment naïve HIV-positive patients in Indonesia. J Int AIDS Soc. 2014;17:18844.

25. Piroth L, Duong M, Quantin C, Abrahamowicz M, Michardiere R, Aho LS, et al. Does hepatitis $\mathrm{C}$ virus co-infection accelerate clinical and immunological evolution of HIV-infected patients? AIDS. 1998;12:381-8.

26. Kottilil S, Chun TW, Moir S, Liu S, McLaughlin M, Hallahan CW, et al. Innate immunity in human immunodeficiency virus infection: effect of viremia on natural killer cell function. J Infect Dis. 2003;187:1038-45.

27. Borrow $\mathrm{P}$, Bhardwaj N. Innate immune responses in primary HIV-1 infection. CurrOpin HIV AIDS. 2008;3:36-44.

28. Scott-Algara D, Truong LX, Versmisse P, David A, Luong TT, Nguyen NV, et al. Cutting edge: increased NK cell activity in HIV-1-exposed but uninfected Vietnamese intravascular drug users. J Immunol. 2003;171: 5663-7.

29. Truong LX, Luong TT, Scott-Algara D, Versmisse P, David A, Perez -Bercoff D, et al. CD4 cell and CD8 cell-mediated resistance to HIV-1 infection in exposed uninfected intravascular drug users in Vietnam. AIDS. 2003;17:1425-34. 
30. Donahoe RM, Vlahov D. Opiates as potential cofactors in progression of HIV-1 infections to AIDS. J Neuroimmunol. 1998;83:77-87.

31. Steele AD, Henderson EE, Rogers TJ. Mu-opioid modulation of HIV-1 coreceptor expression and HIV-1 replication. Virology. 2003;309:99-107.
32. de Souza MS, Karnasuta C, Brown AE, Markowitz LE, Nitayaphan S, Garner RP, et al. A comparative study of the impact of HIV infection on natural killer cell number and function in Thais and North Americans. AIDS Res Hum Retroviruses. 2000;16:1061-6. 